\title{
Seasonal variations of vegetation patterns and biomass constituents in the rocky eulittoral of Helgoland
}

\author{
I. M. Munda ${ }^{1}$ \& J. W. Markham ${ }^{2}$ \\ 1 Biological Institute, Slovene Academy of Science and Arts; \\ Ljubljana, Yugoslavia \\ 2 Biologische Anstalt Helgoland (Meeresstation); \\ D-2192 Helgoland, Federal Republic of Germany
}

\begin{abstract}
Seasonal changes in vegetation patterns and biomass of benthic algae were recorded over a 14-month period in the rocky eulittoral of the North Sea island of Helgoland. The area is characterized by the dominance of Fucus serratus throughout most of the eulittoral and this is reflected in higher biomass of $F$. serratus and relatively fewer other species than on many European rocky shores. Fresh-weight biomass of $F$. serratus ranged seasonally from $4.3 \mathrm{~kg}$ to $15 \mathrm{~kg} \mathrm{~m}^{-2}$ in the center of its extensive distribution. Biomass was also recorded monthly, when the plants were present, for Blidingia spp., Enteromorpha spp., UIva lactuca, Fucus spiralis, F. vesiculosus, Porphyra linearis, P. umbilicalis, Chondrus crispus, Corallina officinalis, Dumontia incrassata, Petalonia fascia, $P$. zosterifolia and Scytosiphon lomentaria. New generations of several species which reappeared after a destructive winter storm showed a higher protein content than in the previous year. The winter and early spring flora of Helgoland shows several resemblances in species composition to the summer flora of Scandinavia.
\end{abstract}

\section{INTRODUCTION}

The benthic algal vegetation of the island of Helgoland has been studied extensively. Kuckuck (1892), Nienburg (1925) and den Hartog (1959) described the eulittoral vegetation and Lüning (1969) reported on standing crop in the upper sublittoral and described (1970) the sublittoral vegetation. Kornmann \& Sahling (1977) recently treated the entire algal flora taxonomically and Markham \& Munda (1980) described the process of recolonization on cleared plots. Despite all these studies, little information is available on seasonal variations in vegetation patterns in undisturbed sites, and there are practically no data on the biomass of the eulittoral vegetation.

In the present study, seasonal variations in vegetation patterns were followed in the Helgoland eulittoral and biomass measurements were carried out in the most conspicuous perennial and seasonal populations of benthic algae.

\section{INVESTIGATED AREA}

The study area is the rocky eulittoral area ("Felswatt") below the sea cliffs on the west side of Helgoland, in the vicinity of the cliff formation known as "Seehundshorn". 
Beneath the sea cliffs is a granite and concrete sea wall. Below this sea wall are numerous large granite blocks, left after the wartime destruction of an earlier sea wall, and many smaller basalt and smooth sandstone boulders. Most of the area of the eulittoral consists of gently sloping, relatively soft red sandstone ("Buntsandstein"), with occasional patches of sand, and numerous rock pools, lagoons, and channels.

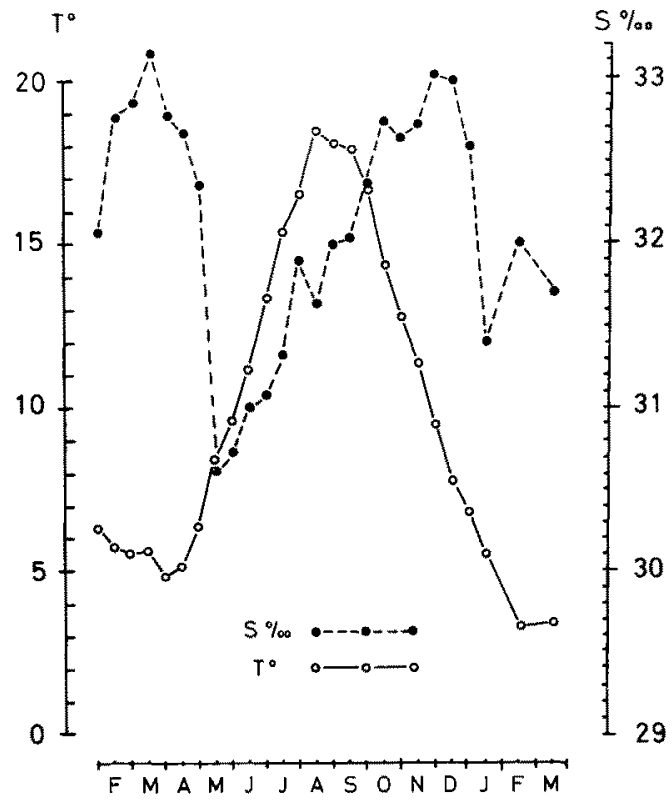

Fig. 1. Helgoland. Hydrographic data for the period February 1975 - April 1976

The tides are semidiurnal with a mean range of $2.3 \mathrm{~m}$ (Anon., 1976). Desiccation and exposure to surf vary greatly with weather. Storms from the west cause extremely heavy surf, but the water can be totally flat with no surf at all during calm weather. During the period studied the monthly mean seawater temperature ranged from a high of $18.2^{\circ} \mathrm{C}$ for August 1975 to a low of $3.1^{\circ} \mathrm{C}$ for February 1976 (Fig. 1). The low was $0.5^{\circ} \mathrm{C}$ below the ten-year (1965-1975) average temperature for February and the high was $1.2^{\circ} \mathrm{C}$ above the ten-year average for August. Monthly mean air temperature ranged from $19.5^{\circ} \mathrm{C}$ in August $1975\left(3.0^{\circ} \mathrm{C}\right.$ higher than the $1953-1972$ average) to $1.7^{\circ} \mathrm{C}$ in February $\left(0.3^{\circ} \mathrm{C}\right.$ above the 20-year average) (Weather Station Helgoland, pers. comm.). Rainfall for the 13-month period was $632 \mathrm{~mm}$, which is $123 \mathrm{~mm}$ below the 20-year average, with the greatest rainfall occurring in September $1975(94 \mathrm{~mm})$ and January $1976(84 \mathrm{~mm})$. In the winter of 1975-1976 a number of severe storms hit the area and on 3 January, 1976 an especially severe storm with hurricane force winds and high water $4 \mathrm{~m}$ above normal struck the area and inflicted visible damage.

In overview, the general zonation pattern is as follows (Fig. 2). On the sea wall, in the littoral fringe and uppermost eulittoral zone, the highest level is occupied by Bangia atropurpurea, followed in vertical sequence by Ulothrix spp. with Hormiscia penicillifor- 
mis, Blidingia marginata, Blidingia minima, Porphyra umbilicalis, and Fucus spiralis. On the high rocks below the sea wall Enteromorpha spp. and Fucus spiralis predominate and mingle with Fucus vesiculosus. This is mostly mixed with the other Fucus species rather than forming a clear belt alone. The mid-eulittoral is dominated by extensive stands of Fucus serratus which extend down to the uppermost sublittoral where the

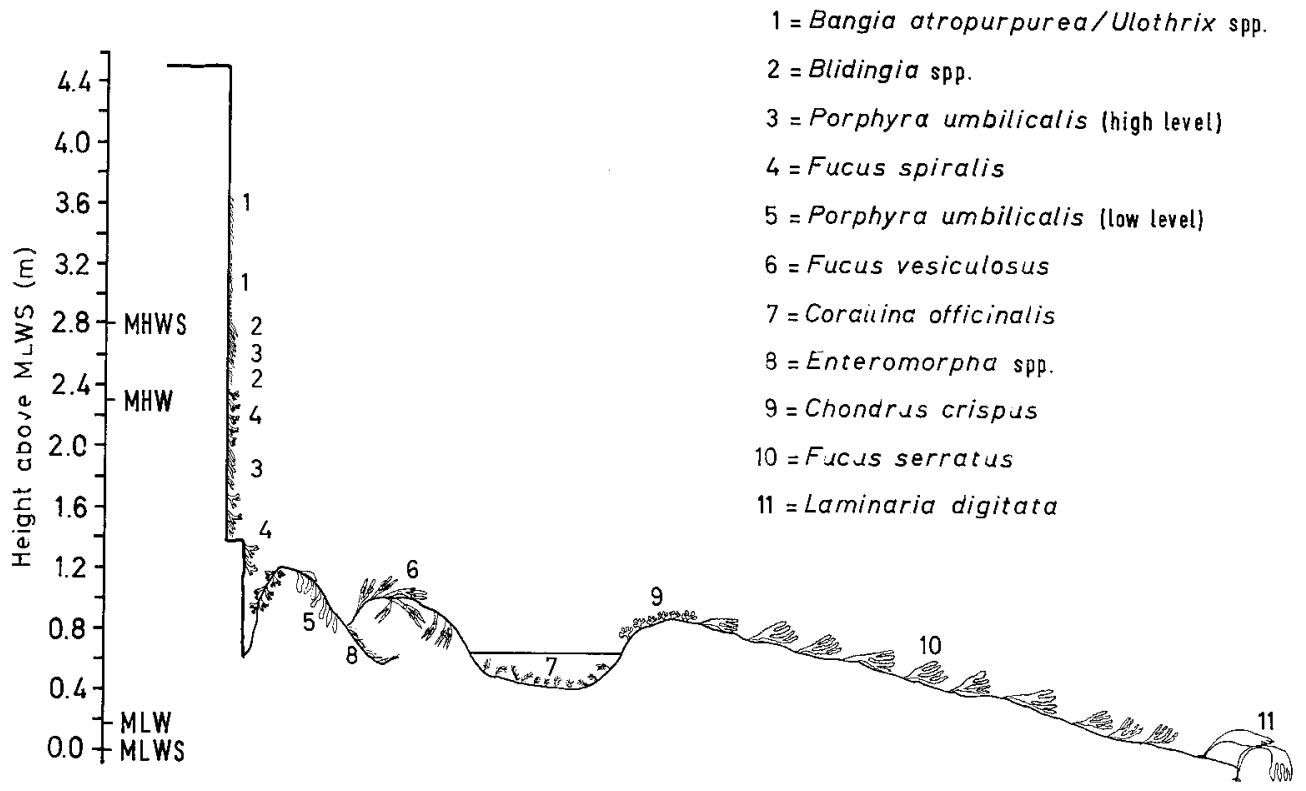

Fig. 2. Helgoland, west side. General zonation pattern in area investigated

uppermost Laminaria digitata plants are found. The most important undergrowth species under the Fucus serratus are Corallina officinalis and Chondrus crispus. Also on emerged areas in the mid and lower eulittoral which are not covered by Fucus serratus the perennial vegetation is represented by Corallina officinalis and Chondrus crispus. In some tide pools of the mid and upper eulittoral, the vegetation has a very seasonal character, and the pools are barren of vegetation in fall and winter. In other pools, Corallina officinalis and Chondrus crispus are perennial elements. Pools in the lower eulittoral contain prolific stands of Chondrus crispus. Deep rocky lagoons are dominated by Laminaria digitata.

\section{METHODS}

Monthly observations were made on the vegetation patterns in the area described. Only species important in the general vegetation pattern were considered (Table 1) as this contribution is not intended to be a complete floristic inventory of the sample sites. Nomenclature of the species mentioned follows Kornmann \& Sahling (1977).

Along with the vegetation studies, samples for biomass determinations were taken from prominent populations of benthic algae at different eulittoral levels in the same 
Table 1. Algal species from Helgoland eulittoral

\begin{tabular}{|c|c|}
\hline Chlorophyta: & Laminaria saccharina (L.) Lamour. \\
\hline Acrosiphonia arcta (Dillw.) J. Ag. & Petalonia fascia (O. F. Müll.) O. Kuntze \\
\hline Acrosiphonia centralis (Lyngb.) Kjellm. & Petalonia zosterifolia (Reinke) Kuntze \\
\hline Acrosiphonia sonderi (Kütz.) Kornm. & Pilayella littoralis (L.) Kjellm. \\
\hline Blidingia marginata (J. Ag.) P. Dang. & Ralfsia verrucosa (Aresch.) J. Ag. \\
\hline Blidingia minima (Näg. ex Kütz.) Kylin & Scytosiphon lomentaria (Lyngb.) Link \\
\hline $\begin{array}{l}\text { Chaetomorpha melagonium (Web. et Mohr) } \\
\text { Kütz. }\end{array}$ & Spongonema tomentosum (Huds.) Kütz. \\
\hline $\begin{array}{l}\text { Chaetomorpha tortuosa (Dillw.) Kütz. } \\
\text { (= C. capillaris (Kütz.) Børq.) }\end{array}$ & $\begin{array}{l}\mathrm{Rh} \text { od op hy ta: } \\
\text { Ahnfeltia olicata (Huds.) Fries }\end{array}$ \\
\hline Cladophora rupestris (L.) Kütz. & Bangia atropurpurea (Roth) C. Ag. \\
\hline Cladophora sericea (Huds.) Kütz. & Ceramium desIongchampsii Chauv. in Duby \\
\hline Codium fragile (Sur.) Hariot & Ceramium rubrum (Huds.) C. Ag. \\
\hline Enteromorpha compressa (L.) Grev. & Chondrus crispus Stackh. \\
\hline Enteromorpha intestinalis (L.) Link & Corallina officinalis $\mathrm{L}$. \\
\hline Enteromorpha linza (L.) J. Ag. & Cystoclonium purpureum (Huds.) Batt. \\
\hline Enteromorpha prolifera (O. F. Müll.) J. Ag. & Dumontia incrassata (O. F. Müll.) Lamour. \\
\hline $\begin{array}{l}\text { Hormiscia penicilliformis (Roth) Fries } \\
\text { (= Urospora penicilliformis [Roth] Aresch.) }\end{array}$ & $\begin{array}{l}\text { Furcellaria lumbricalis (Huds.) Lamour. } \\
\text { Hildenbrandia rubra (Sommerf.) Menegh. }\end{array}$ \\
\hline Monostroma grevillei (Thur.) Wittr. & Membranoptera alata (Huds.) Fries \\
\hline Monostroma undulatum Wittr. & Petrocelis hennedyi (Harv.) Batt. \\
\hline Spongomorpha aeruginosa (L.) Hoek & Phymatolithon laevigatum (Fosl.) Fosl. \\
\hline Ulothrix spp. & Phymatolithon lenormandii (Aresch. in J. Ag.) \\
\hline Ulva lactuca L. & $\begin{array}{l}\text { Adey } \\
\text { Phymatolithon polymorphum (L.) Fosl. }\end{array}$ \\
\hline Phaeophyta & Polysiphonia nigrescens (Huds.) Grev. \\
\hline Chordaria flagelliformis $(\mathrm{O}$ & Polysiphonia urceolata (Lightf. ex Dillw.) \\
\hline Desmarestia viridis (O. F. Müll.) Lamour. & Grev. \\
\hline Ectocarpus fasciculatus Harv. & Porphyra leucosticta Thur. in Le Jol. \\
\hline Ectocarpus siliculosus (Dillw.) Lyngb. & Porphyra linearis Grev. \\
\hline Elachista fucicola (Vell.) Aresch. & Porphyra umbilicalis (L.) J. Ag. \\
\hline Fucus serratus L. & Rhodomela confervoides (Huds.) Silva \\
\hline Fucus spiralis $\mathrm{L}$. & Rhodomela virgata Kjellm. \\
\hline Fucus vesiculosus $\mathrm{L}$. & Rhodophysema elegans (Crouan frat. ex \\
\hline Laminaria digitata (Huds.) Lamour & J. Ag.) Dixon \\
\hline
\end{tabular}

area at monthly intervals over the period March 1975 to April 1976. A 1/4 $\mathrm{m}^{2}$ unit was used for extensive populations and a $1 / 16 \mathrm{~m}^{2}$ unit was used for populations occupying small areas. The fresh weight per unit area was determined for the dominant algae measured and the biomass expressed as $\mathrm{g} \mathrm{m}^{-2}$. Dry weight was estimated by drying the samples at $90^{\circ} \mathrm{C}$ for 12 hours. Of the biomass constituents, only ash and protein contents were estimated. The ash content was determined by combustion at $400{ }^{\circ} \mathrm{C}$ for 12 hours and the total nitrogen by the Kjeldahl procedure, thereby calculating the protein content. Protein and ash content were expressed as a percentage of dry weight. In mixed populations, the algal growth was separated into the main species, which were then weighed and analyzed separately. All figures presented here are based on one sample per month. Where multiple samples were taken, they confirmed the results presented here. 


\section{RESULTS}

\section{Vegetation Patterns}

The general vegetation patterns observed in the investigated areas throughout the year are described here for the various vertical zones separately.

\section{Littoral fringe and uppermost eulittoral}

The highest point considered in this study is on the sea wall in the littoral fringe (Lewis, 1964) at, and slightly above, the height of the predicted highest high water on a windless day ( $2.8 \mathrm{~m}$ above MLWS). At this point on the sea wall there is a boundary between concrete above and granite below. The uppermost eulittoral includes the blocks and boulders lying at the foot of the wall.

\section{Winter aspect}

This zone was dominated in winter by a prolific and broad belt (up to $2.5 \mathrm{~m}$ vertically) of Porphyra linearis which first appeared as small specimens in November, reached a peak in February, and finally declined in March and disappeared in April. The belts of Ulothrix spp. - Hormiscia penicilliformis were completely obscured by $P$. linearis. Likewise Bangia atropurpurea, prolific from December to March above the Ulothrix-Hormiscia belt, was largely covered by $P$. linearis.

Lower down on the sea wall, Porphyra umbilicalis was sparse and poorly developed in winter as was the uppermost Fucus spiralis population. Blidingia spp. (B. minima and B. marginata) was especially prolific in November at the same level as Porphyra umbilicalis and was present throughout the winter despite the severe storms in January which destroyed much of the algal population. These Blidingia populations are pseudoperennial, as Blidingia is present throughout the year in several overlapping generations. Likewise, Enteromorpha spp. is pseudoperennial on the upper blocks and boulders. In this year the Porphyra umbilicalis stands and much of the Enteromorpha spp. decreased markedly after the January storms. Smooth boulders of red sandstone were devoid of any vegetation for much of the winter.

In February, with continuing storms, the Porphyra linearis population reached a peak, while Enteromorpha spp. disappeared nearly totally and Porphyra umbilicalis deteriorated further.

\section{Spring aspect}

During spring, the Bangia atropurpurea belt gradually deteriorated and the high level vegetation came to be dominated by Ulothrix spp. and Hormiscia penicilliformis above, Blidingia marginata somewhat lower, and Blidingia minima yet lower. The Blidingia belts were much more prolific during the spring of 1975 than during the next spring.

On the uppermost granite and basalt boulders Enteromorpha spp. (primarily $E$. prolifera and $E$. compressa) began to reappear. The smooth sandstone boulders remained mostly devoid of vegetation throughout the spring with only Hormiscia penicilliformis in some fissures.

In the course of the spring a gradual increase in the density of the Porphyra umbilicalis population on the lower wall was observed. This increase occurred earlier, 
mostly in April and May during the first spring, and was shifted toward May and June the second spring.

Fucus spiralis increased in density during April and May of 1975, but showed no recovery from the winter condition during the spring of 1976.

\section{Summer aspect}

The Bangia belt disappeared completely and the uppermost vegetation was represented almost solely by a belt of Ulothrix spp. and Hormiscia spp. Blidingia also declined considerably. The uppermost Porphyra umbilicalis increased in density and biomass through July and August. The upper Fucus spiralis also was more prolific in summer. Enteromorpha spp. (including E. prolifera, E. intestinalis and E. compressa) appeared as juvenile plants on the smooth sandstone boulders and reached a peak on the other boulders where they had already appeared in spring.

\section{Autumn aspect}

During autumn a general improverishment of the high level vegetation became obvious. Porphyra umbilicalis declined rapidly, and Enteromorpha largely disappeared. Ulothrix spp., Hormiscia spp. and Blidingia marginata remained largely unchanged. Blidingia minima increased slightly and reached a peak in November.

\section{Upper eulittoral}

The area where Fucus vesiculosus is most abundant $(+1.0$ to $+1.2 \mathrm{~m}$ above MLWS) is considered here as the upper eulittoral. Although Fucus vesiculosus is more abundant here than anywhere else, it seldom forms a pure stand and is usually mixed with $F$. spiralis and $F$, serratus. Fucus vesiculosus occurs mostly as a rather sparsely vesiculated form, or even completely bladderless. Along with this dominant form are some specimens of the typical, heavily vesiculated form. Forms which might possibly represent hybrids with $F$. serratus and $F$. spiralis were also found. The undergrowth of the fucoids is poorly developed here and has as perennial elements mostly Hildenbrandia rubra and Ralfsia verrucosa, with some low-level Blidingia minima, Hormiscia penicilliformis and Ulothrix spp. A separate lower-level population of Fucus spiralis is found here, spatially separated from the upper population considered in the uppermost eulittoral. The substrate here consists of round stones, granite blocks, and boulders. Seasonal variations at this level occurred mainly in the rock surfaces not covered by Fucus; in the Fucus populations, little change was evident.

\section{Winter aspect}

During winter the vegetation at this level was rather impoverished. Most of the rocks not covered by Fucus were bare of any vegetation.

\section{Spring aspect}

Low-level populations of Porphyra umbilicalis appeared in spring, increasing in density throughout the entire spring. These plants were much more prolific during the first year of observation than in the second year. Enteromorpha spp. appeared on some previously bare rocks but some rocks remained bare during spring. The fucoid populations at this level showed essentially no change from winter. 
Summer aspect

In summer Porphyra umbilicalis reached a peak in density and was the dominant alga on boulders and smaller rocks at this level. Enteromorpha linza and E. prolifera grew larger where they had already started in spring and covered all the previously bare rocks. The Fucus populations reached a peak in density and most were fertile. Plants of the linear, bladderless to poorly vesiculated form of $F$. vesiculosus were fertile, whereas most of the plants of the typical form of $F$. vesiculosus were not fertile.

Autumn aspect

Beginning in September the Porphyra umbilicalis population declined and then disappeared from the vegetation, as did Enteromorpha linza. Fucus spiralis retained a high density whereas the density of the other Fucus stands declined. Rocky surfaces left bare by the disappearance of Porphyra umbilicalis and Enteromorpha linza remained clean throughout the rest of the autumn.

\section{Mid-eulittoral and lower eulittoral}

The mid-eulittoral (1.0 to $0.4 \mathrm{~m}$ above MLWS) and lower eulittoral $(0.4$ to $0.0 \mathrm{~m}$ above MLWS) are treated together here because the entire range is covered by extensive stands of Fucus serratus. This includes the upper portion of the mid-eulittoral which on other shores is more typically dominated by Fucus vesiculosus, and the lower portion of the Iower eulittoral where Fucus serratus extends down to the uppermost Laminaria digitata.

\section{Winter aspect}

Rocky slopes not covered by Fucus serratus were mostly clean and bare during the winter except for occasional small stands of Chondrus crispus. In parts of the upper levels of the mid-eulittoral bare rocks were covered by juvenile Ulva lactuca and Enteromorpha compressa left over from the previous summer. The undergrowth under Fucus serratus consisted mainly of perennial elements. These included several crustaceous species such as Phymatolithon lenormandii, $P$. laevigatum, $P$. polymorphum, Rhodophysema elegans, Petrocelis hennedyi, Ralfsia verrucosa and Hildenbrandia rubra. Perennial stands of Chondrus crispus and Corallina officinalis were represented in the undergrowth. Chondrus was more abundant at lower levels. Some Cystoclonium purpureum, Ceramium rubrum, Polysiphonia urceolata and Rhodomela confervoides were also found in the undergrowth during winter. Also present in the upper level undergrowth were Enteromorpha spp., Ectocarpus siliculosus, Pilayella littoralis, Hormiscia spp. and Ulothrix spp. In general the winter vegetation of these levels is rather uniform and low in species diversity, and consists mostly of perennial elements.

\section{Spring aspect}

As spring progressed, several new species appeared in the vegetation, both in the undergrowth and on exposed rock surfaces. Beginning in March, Dumontia incrassata appeared and became very prominent. It covered the bare rock surfaces in dense continuous mats and dominated in the undergrowth. Prolific stands of Petalonia spp. also appeared, mostly on bare rock surfaces and more rarely in the undergrowth. Petalonia zosterifolia was found in great abundance from March on, especially at higher levels, while $P$. fascia appeared first in April and persisted longer. Considerable quantities of Ceramium rubrum, C. deslongchampsii, and Cystoclonium purpureum were found in 
the undergrowth, while Rhodomela confervoides was frequent on lower areas of previously bare rock. Scytosiphon lomentaria was also prominent in the spring vegetation, mostly as single specimens rather than continuous stands. Cladophora rupestris was prominent in early spring, in belts underneath Fucus serratus.

The proportion of green algae in the vegetation increased during spring. Acrosiphonia spp. (A. arcta, A. centralis, A. sonderi) appeared on bare areas in the lower eulittoral and formed continuous stands in late spring while on the higher levels Enteromorpha spp. appeared on bare rock surfaces in continuous stands along with Petalonia spp. and Cladophora rupestris declined. Scattered single specimens of Codium fragile and Furcellaria lumbricalis were found near the lower limit of the eulittoral on isolated bare areas within the Fucus stands. Monostroma spp. (M. grevillei \& M. undulatum) appeared later, mainly as epiphytes on Fucus and Corallina officinalis. Other epiphytes on Fucus included Enteromorpha spp., Spongomorpha aeruginosa, Ectocarpus fasciculatus, E. siliculosus, Elachista fucicola, Pilayella littoralis, Spongonema tomentosum, Ceramium rubrum and Polysiphonia urceolata.

\section{Summer aspect}

During summer Fucus serratus and its associated vegetation reached a peak in biomass and diversity. Chondrus crispus, Corallina officinalis, and Ceramium rubrum were all extremely abundant. Many young sporelings of Chondrus crispus were observed.

In summer, the rocks not covered by Fucus were largely dominated by green algae. As the season progressed, green algae became more and more abundant, especially Ulva lactuca and Enteromorpha linza, which dominated vast open areas and also extended into the undergrowth under Fucus serratus. Enteromorpha spp. (mostly E. prolifera) appeared on slopes which had been occupied by Petalonia spp. in spring. Chaetomorpha tortuosa appeared in dense tufts on open slopes and Chaetomorpha melagonium occurred as single specimens among the Fucus plants.

The beginning of the summer showed a greater diversity than later. Thus, Cladophora sericea and Porphyra leucosticta both appeared in early summer, the Porphyra in considerable abundance and mostly epiphytic, but both disappeared by the end of July.

Chordaria flagelliformis was found occasionally with Enteromorpha linza in the first summer. During the second summer, not a plant of Chordaria was found.

\section{Autumn aspect}

In late summer and early autumn most of the green algae disappeared and a general floristic impoverishment was evident. The rocks were gradually denuded of all seasonal plants and surfaces not covered by Fucus were mostly bare and clean by mid-autumn. Cystoclonium purpureum, Polysiphonia urceolata and Ceramium spp. were all rare. The undergrowth under Fucus serratus was reduced to perennial elements. The Chondrus crispus and Corallina officinalis populations became less dense.

\section{Tide pools and lagoons}

The most pronounced seasonal fluctuations in vegetation patterns were noted in the tide pools and deep lagoons. As noted above, there are 3 main types of pools and 
lagoons; the pools in the upper and mid-eulittoral which are devoid of most vegetation in fall and part of the winter; those which contain perennial stands of Chondrus crispus or Corallina officinalis; and the deep lagoons which are dominated by Laminaria digitata, with an under-growth of red algae.

\section{Winter aspect}

Early in the winter the upper pools were nearly devoid of any vegetation, with only a few crustaceous algae such as Ralfsia verrucosa, Phymatolithon lenormandii and Hildenbrandia rubra and occasional isolated small tufts of Corallina officinalis present. In the latter part of December and in January three red algal species appeared and became abundant in the pools: Polysiphonia nigrescens, Ceramium rubrum and Rhodomela confervoides. The same algae were found in the Chondrus and Corallina pools as epiphytes and were the most obvious vegetation in the pools in the latter half of the winter. The same three red algal species were also very abundant in the deep lagoons during winter. Here, however, the dominant vegetation was Laminaria digitata with some L. saccharina. Also present were Desmarestia viridis, Chondrus crispus, Corallina officinalis, Rhodomela virgata, Membranoptera alata, Ahnfeltia plicata, Furcellaria lumbricalis. The crustaceous algae consisted of most of the same species as the undergrowth under Fucus serratus except that Hildenbrandia rubra was more rare.

\section{Spring aspect}

In spring the general appearance of the pools, particularly the upper pools, changed considerably. Two species, Polysiphonia nigrescens and Rhodomela confervoides, disappeared during the course of the spring. Dumontia incrassata came to dominate most of the upper pools. Acrosiphonia spp. in large stands occurred in some pools and Scytosiphon lomentaria became abundant although it seldom occurred in continuous stands.

In pools with a perennial Corallina population, Monostroma grevillei and $M$. undulatum developed as epiphytes in considerable quantity. Dumontia incrassata was also found in these pools although less abundantly than in the higher pools. Ceramium spp., Polysiphonia urceolata and Cystoclonium purpureum also appeared in these pools.

In the deep lagoons Chondrus crispus became more abundant as did most of the other reds found here in winter. Dumontia incrassata was also found in these lagoons, but in considerably less quantity than in the upper pools. In May Cladophora sericea appeared in most of the pools and rapidly began increasing in abundance.

In general the pools were dominated in spring by red algae, particularly Dumontia incrassata. Only in late spring was this dominance challenged by the increase of Cladophora sericea.

\section{Summer aspect}

In contrast to the red algal dominance in spring, the pools were dominated in summer by green algae. Dumontia incrassata disappeared early in the summer. Cladophora sericea reached a peak in June with very extensive stands but then disappeared from the vegetation in July along with Scytosiphon lomentaria. Acrosiphonia spp. also declined and finally disappeared over the course of the summer. Ulva lactuca and Enteromorpha linza appeared in ever increasing quantity and came to dominate the upper pools almost completely. Chaetomorpha tortuosa was found in large dense tufts in the upper pools as well as in the Corallina and Chondrus pools. 
In the Corallina pools Porphyra leucosticta appeared in early summer then disappeared in July along with the epiphytic Monostroma spp. Chaetomorpha tortuosa was found as an epiphyte on Corallina and Chondrus early in the summer but later these red algae were completely covered by Ulva lactuca and Enteromorpha linza. In some deeper pools the two dominant species were Ceramium rubrum and Ulva lactuca, which penetrated deeper than Enteromorpha. Ulva lactuca was also very prominent in the deep Laminaria lagoons.

The general picture in summer was one of pools largely dominated by Ulva lactuca, with Enteromorpha linza also very important.

During autumn much of the tide pool vegetation deteriorated and disappeared. Ulva lactuca and Enteromorpha linza largely disappeared. The upper pools were practically clean of any vegetation from September on. In the Corallina and Chondrus pools the epiphytic and other seasonal species disappeared. The number of species likewise declined greatly in the deep lagoons, although some red algae, such as Ceramium rubrum and Rhodomela confervoides persisted.

\section{Biomass}

Blidingia spp. (mixed B. minima and $B$. marginata) forms a conspicuous belt in the uppermost eulittoral at the upper level of the seawall throughout the year, although as several overlapping generations. Blidingia marginata predominated in the upper parts of the belt and $B$. minima somewhat lower. The two species forming the belt were treated as an entity for biomass measurements. Blidingia spp. reached a biomass peak of $1900 \mathrm{~g}$ $\mathrm{m}^{-2}$ in March and a minimum of $66 \mathrm{~g} \mathrm{~m}^{-2}$ in January after the big storm (Fig. 3). Ash ranged from 23 to $54 \%$ of dry weight and protein from 13 to $31 \%$ (Fig. 4). The minimum

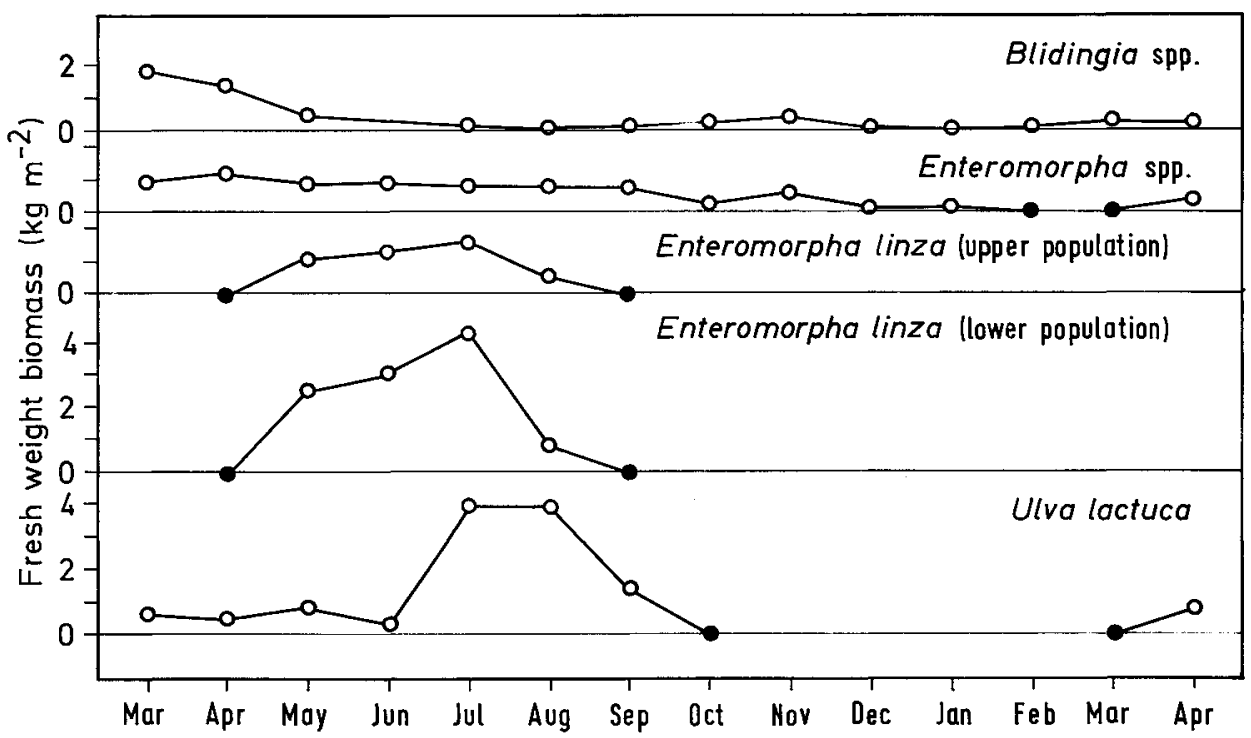

Fig. 3. Biomass values for species of Chlorophyta investigated $\left(\mathrm{kg} \mathrm{m}^{-2}\right)$ 
in ash and protein content coincided with the biomass minima in January. The peaks in protein content coincided with the appearance of new generations in the vegetation.

On rock surfaces which are not covered by fucoids, especially the smoother surfaces, populations of Enteromorpha spp. are found all year as several overlapping generations, although much more abundantly in spring and summer. The populations consist of various species, including $E$. compressa and $E$. intestinalis. They are considered together here as Enteromorpha spp. The population reached a maximum biomass of $1245 \mathrm{~g} \mathrm{~m}^{-2}$ in spring, declined from May to August, and then fell more sharply during the fall and winter (Fig. 3). Most of the plants disappeared during the winter, although a few remained. A new generation appeared in April and again in June and July. A further new generation appeared again in December but was almost completely removed by the January storm. Ash ranged from 32 to $61 \%$ of dry weight and protein from 12 to $34 \%$ (Fig. 4). As the plants became older, the ash content increased while the protein content decreased.

Enteromorpha linza is an important element of the summer flora in the mideulittoral. It was present in two distinct populations, a pure population higher up and a

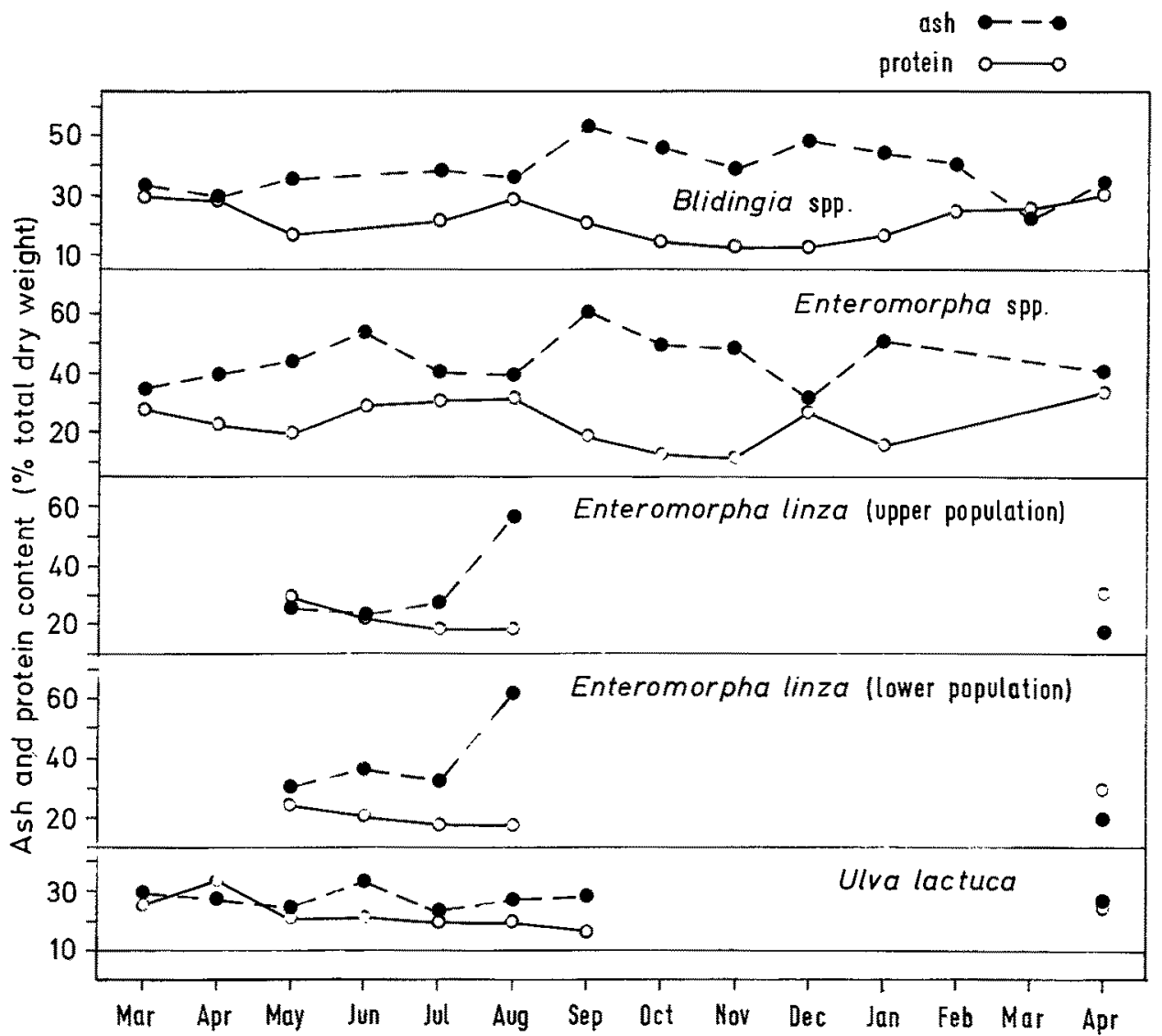

Fig. 4. Ash and protein contents for species of Chlorophyta investigated (g $100 \mathrm{~g} \mathrm{dry}_{\mathrm{weight}}^{-1}$ $=\%$ total dry weight) 
population mixed with Ulva lactuca somewhat lower down in the eulittoral. The plants were present in the vegetation from the end of May to the beginning of September. For both populations the biomass reached a maximum at the beginning of July. The lowlevel population had a much higher biomass and ash content but lower protein content than the high-level population (Figs 3,4). Ash content showed a maximum in both populations in mid-August but a minimum in late May for the lower population and in mid-June for the upper population. Protein content in both populations showed a maximum in late May and a minimum value in mid-August, before they died out. The

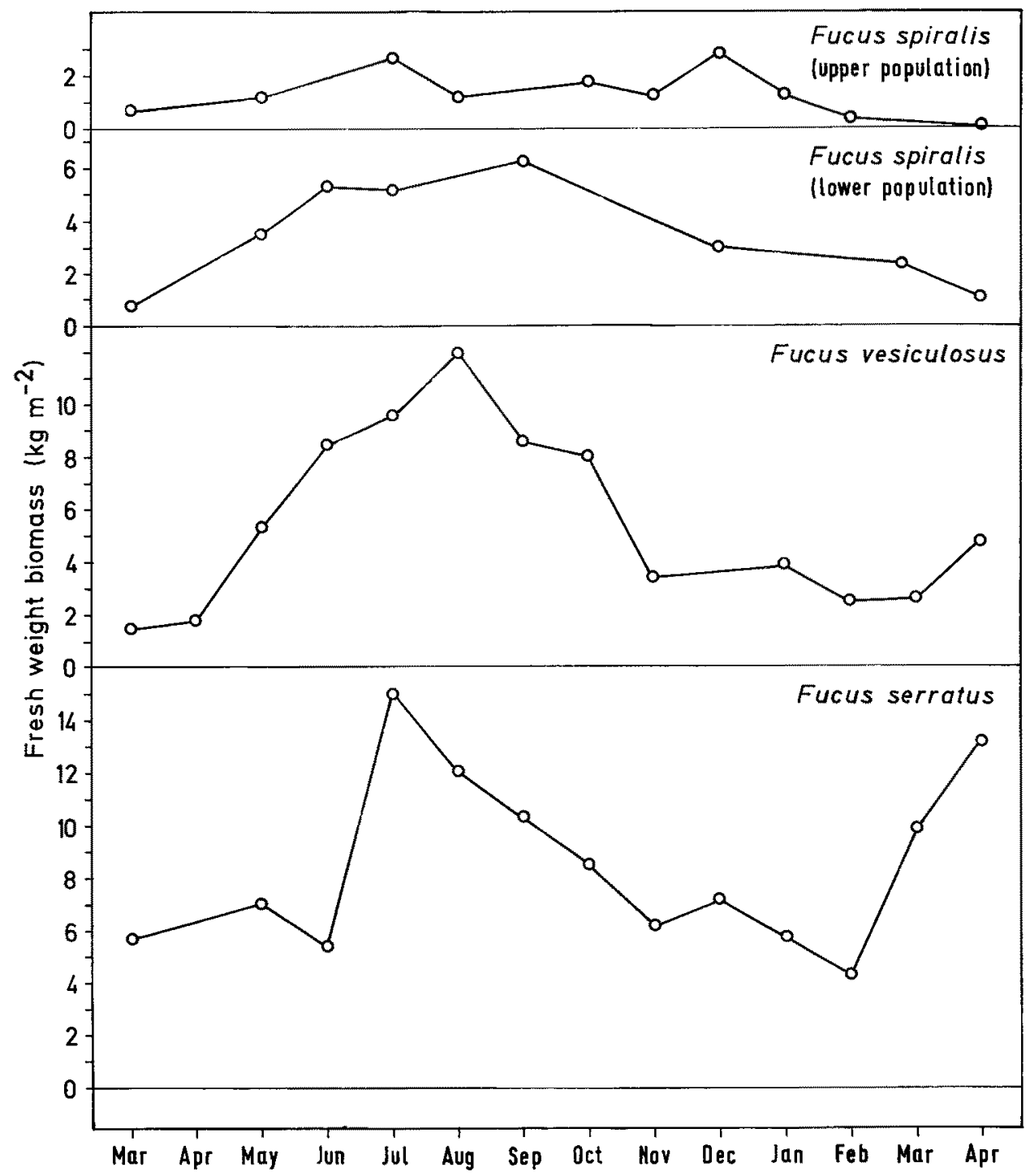

Fig. 5. Biomass values for species of Phaeophyta investigated $\left(\mathrm{kg} \mathrm{m}^{-2}\right)$ 
new populations measured in April 1976 showed extremely high protein and low ash contents compared with measurements made in 1975. Maximum biomass for the highlevel population was $1600 \mathrm{~g} \mathrm{~m}^{-2}$; ash ranged from 19 to $57 \%$ of dry weight and protein ranged from 19 to $31 \%$. The lower population had a maximum biomass of $4300 \mathrm{~g} \mathrm{~m}^{-2}$. Ash ranged from 20 to $62 \%$ and protein from 18 to $30 \%$.

Ulva lactuca dominates the summer vegetation of the mid and lower eulittoral on sites where there is no cover of Fucus serratus, especially from March to September. At other times it is present, but rather rare. It occurs in pure populations or mixed with Enteromorpha linza. Biomass showed a rapid increase during June and a peak of $4025 \mathrm{~g}$ $\mathrm{m}^{-2}$ in late July (Fig. 3). The ash content ranged from a peak value of $34 \%$ of dry weight in June to a low of $24 \%$ in July (Fig. 4). Protein content peaked in April at $34 \%$ when the plants were still very young and declined to $17 \%$ in September.

Fucus spiralis forms two distinct perennial populations in the study area, a higher one in the sea wall, overlapping with Blidingia minima, and a lower one on boulders in the upper eulittoral in the Fucus vesiculosus level. The upper-level plants are mostly dwarfed, and were seldom fertile during the year they were observed. The biomass of the high-level population was much lower than that of the low-level population (Fig. 5). Biomass values were high in the upper-level plants in July and peaked in December at $2920 \mathrm{~g} \mathrm{~m}^{-2}$, with a decline toward spring and a low of $180 \mathrm{~g} \mathrm{~m}^{-2}$ in April of the second year. The protein content was somewhat higher in the high-level plants than in the lowlevel plants (Fig. 6). It reached a peak in July and again the following spring of $18 \%$ of dry weight with a minimum in December of $6 \%$. Ash varied only from 21 to $27 \%$.

The low-level population of Fucus spiralis had a much higher biomass and was usually present as pure stands. The plants were larger and were frequently fruiting during the year of observation. Some of the plants showed an intermediate form somewhat between $F$. vesiculosus and $F$. spiralis and may represent hybrids. Biomass

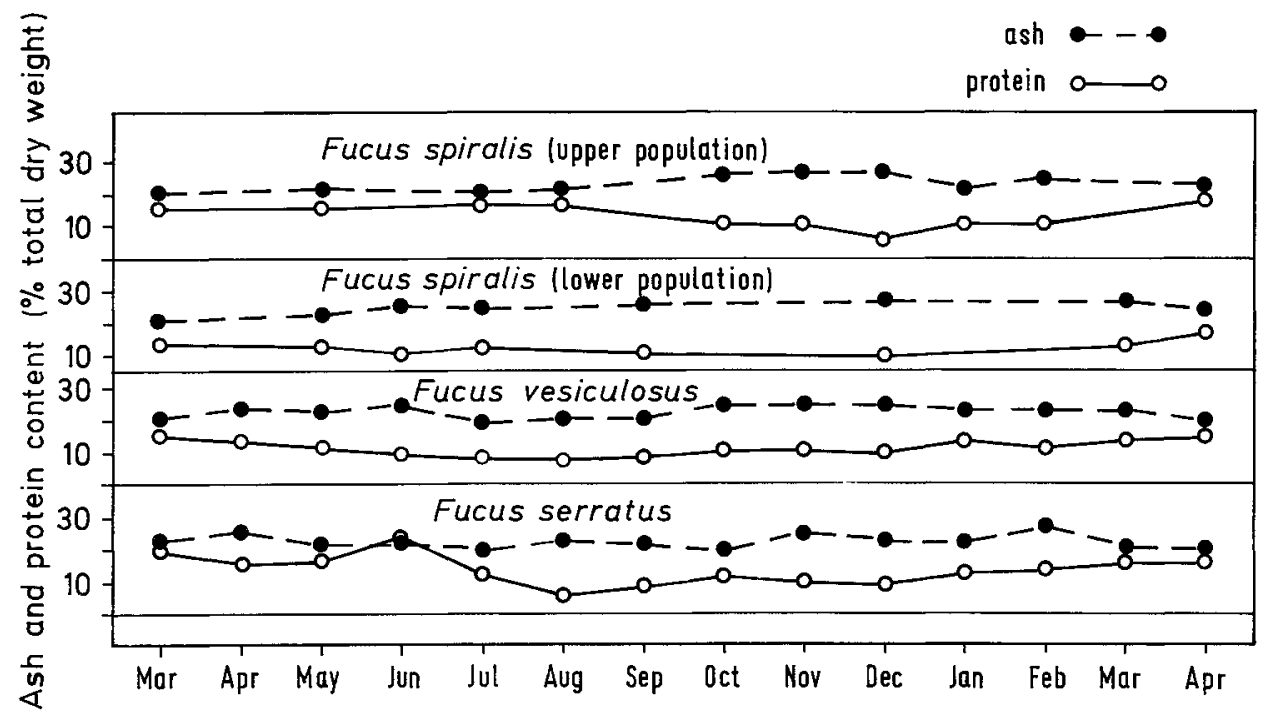

Fig. 6. Ash and protein contents for species of Phaeophyta investigated (g $100 \mathrm{~g} \mathrm{dry} \mathrm{weight}^{-1}$ $=\%$ total dry weight) 
ranged from a minimum in March of $800 \mathrm{~g} \mathrm{~m}^{-2}$ to a maximum in September of $6329 \mathrm{~g}$ $\mathrm{m}^{-2}$. Protein ranged from $10 \%$ in December to $17 \%$ in April of the second year (Fig. 6). Compared with the upper-level population, the plants had a higher average ash content, but the range was the same, 21 to $27 \%$.

Fucus vesiculosus is, like $F$. spiralis, poorly represented on Helgoland and seldom forms pure stands. It is often mixed with $F$. spiralis and $F$. serratus also and possible hybrids are present. It occurs on Helgoland in two perennial forms, a typical, usually vesiculated form, which is in the minority, and a more common form which is very narrow and linear and wholly or partly lacking in vesicles and which appears to be an endemic form for the southern North Sea (see Nienburg, 1927; Nienhuis, 1970). From a low of $1520 \mathrm{~g} \mathrm{~m}^{-2}$, the biomass of the populations of both forms increased through the spring and early summer, reaching a peak in August of $12000 \mathrm{~g} \mathrm{~m}^{-2}$ and then decreasing in the fall (Fig. 5). In comparing the two forms, it was observed that the linear form had a higher ash (ranging form 20 to $25 \%$ of dry weight) and protein content ( 8 to $16 \%$ ) (Fig. $6)$. Its dry weight was usually lower and it was more frequently fertile. The two forms grow side by side at Helgoland and further investigations are necessary to determine whether the differences are genetically fixed. During the year of observations Fucus vesiculosus declined in the upper eulittoral Helgoland vegetation and an upward intrusion of Fucus serratus was noted.

Fucus serratus, the dominant species in the Helgoland eulittoral, has a very large biomass. Samples for biomass determinations were taken in the mid-eulittoral in the center of its extensive distribution. Biomass increased greatly in summer with a peak of $15000 \mathrm{~g} \mathrm{~m}^{-2}$ at the end of July, then declined to a minimum of $4300 \mathrm{~g} \mathrm{~m}^{-2}$ in February (Fig. 5). The protein content of this species showed a peak in March of $20 \%$ of dry

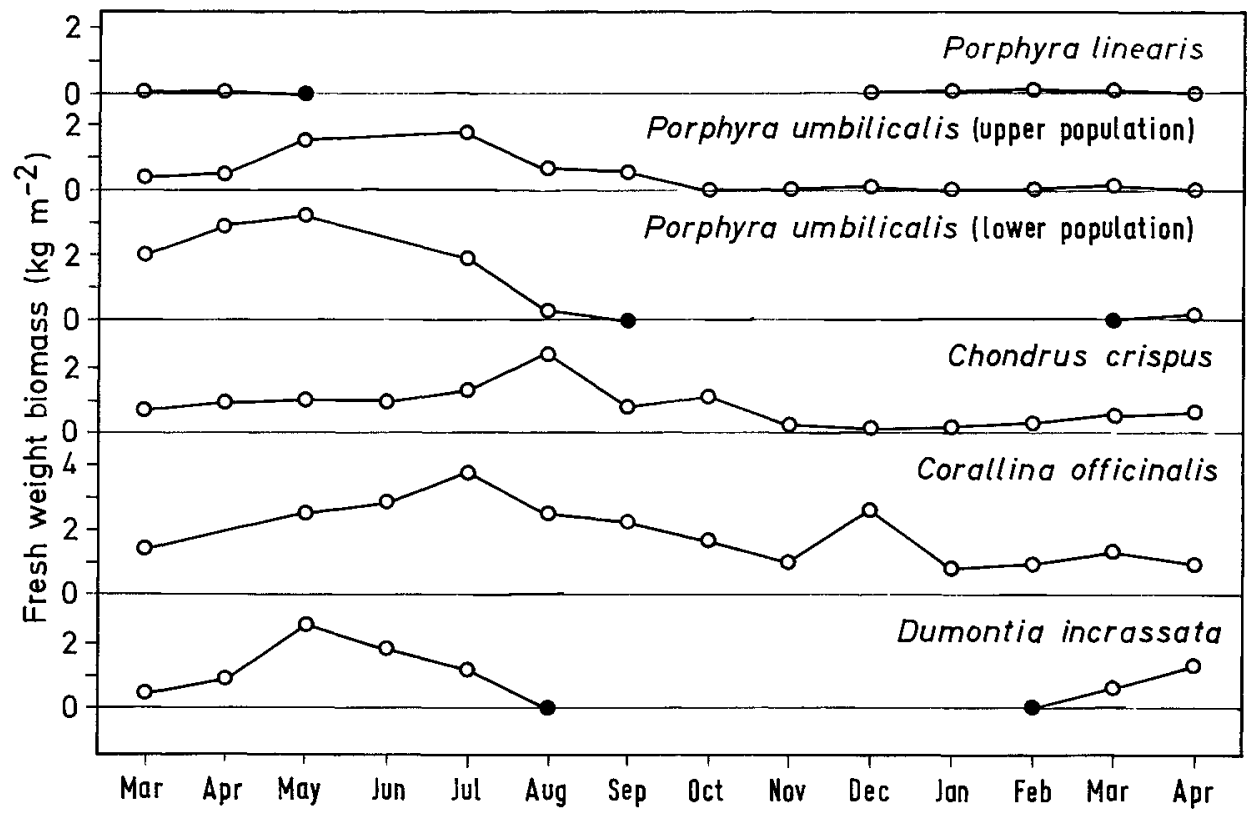

Fig. 7. Biomass values for species of Rhodophyta investigated $\left(\mathrm{kg} \mathrm{m}^{-2}\right)$ 
weight and another peak in June of $24 \%$ and a minimum in August of $6 \%$ (Fig. 6). The ash content showed only minor variations (from 20 to $27 \%$ ) and bore no relation to the seasonal course of the protein content. The increase in biomass during the second spring of observation was notably higher than during the first spring.

Porphyra linearis is an important element of the uppermost eulittoral winter flora on the sea wall. The plants are present from November to late April and form a significant belt from December to April. The biomass increased greatly from December to a peak of $137 \mathrm{~g} \mathrm{~m}^{-2}$ in February (Fig. 7) which was followed by a sharp decline in April. The greatest vertical extent ( $2.5 \mathrm{~m}$ wide) was attained by the population on the sea wall in February 1976, shortly after the big storm. Porphyra linearis had the highest protein content of any of the Helgoland species of Porphyra. The protein content of the plants was higher in the second, more severe winter, when a peak of $40 \%$ of dry weight was reached in January (Fig. 8). The minimum in the ash content (15\%) was also reached in January, following the peak of $23 \%$ in December.

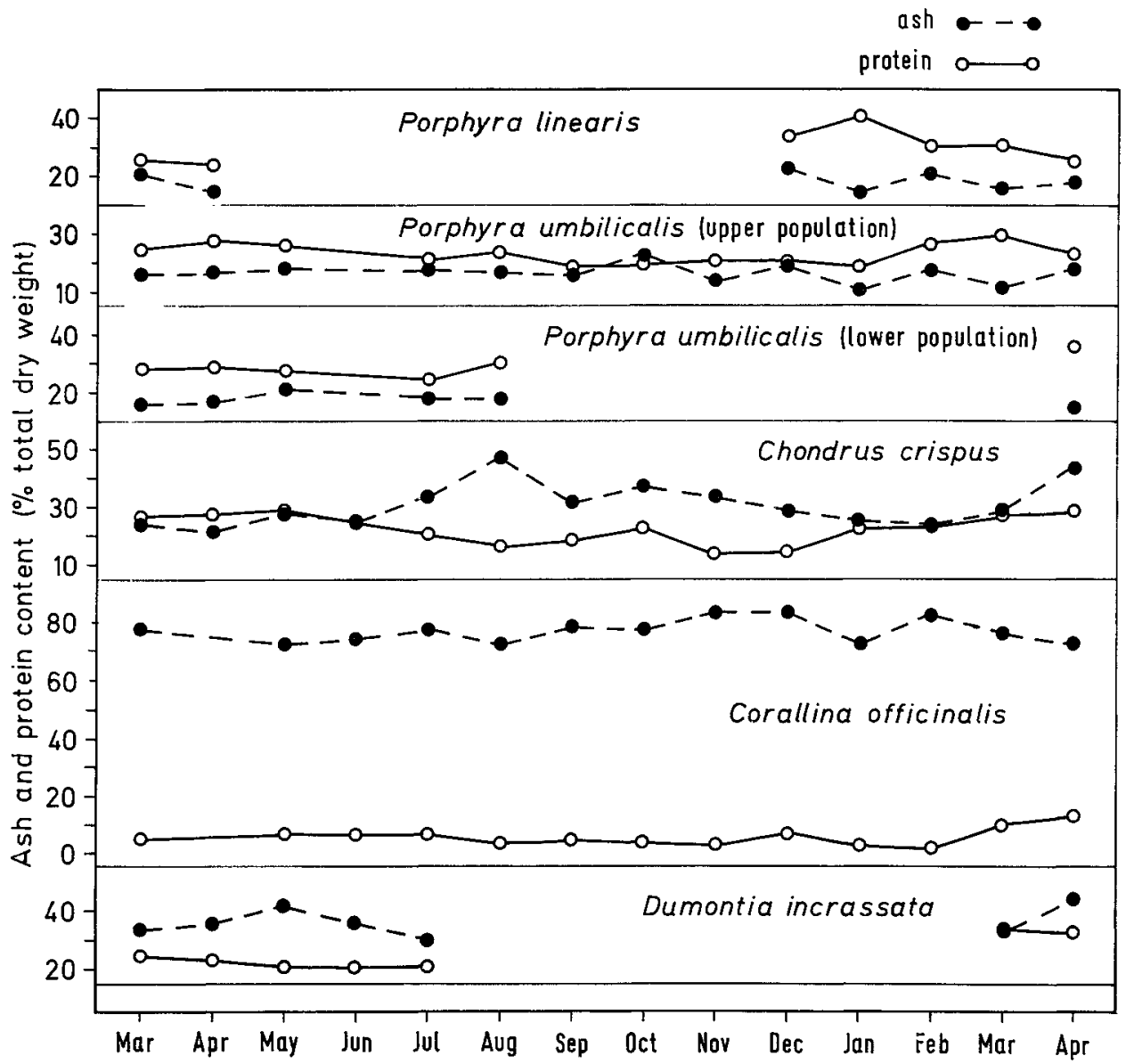

Fig. 8. Ash and protein contents for species of Rhodophyta investigated $\left(\mathrm{g} 100 \mathrm{~g}\right.$ dry weight ${ }^{-1}$ $=\%$ total dry weight) 
Porphyra umbilicalis forms two distinct populations in the study area, a high-level one on the sea wall at the level of Blidingia minima and Fucus spiralis and a low-level population in the upper eulittoral at the level Fucus vesiculosus. The high-level population is pseudoperennial and contains typical plants of $P$. umbilicalis. The low-level population is seasonal, appearing in the vegetation from March to September, and contains plants which are more elongated and flaccid. The occurrence of $P$. umbilicalis at Helgoland was described by Kornmann (1961). The high-level population showed a steep increase in biomass from spring toward summer, with a peak of $1830 \mathrm{~g} \mathrm{~m}^{-2}$ in July (Fig. 7). The biomass then decreased in August, was low in fall and winter, and reached a minimum of $50 \mathrm{~g} \mathrm{~m}^{-2}$ in January after the storm. The protein content was high in spring of both years ( 28 to $30 \%$ ), then declined in July, reached a low of $19 \%$ in September and remained fairly constant from September to January (Fig. 8). The ash content of the plants showed irregular fluctuations (16 to $23 \%$ ) and increased in fall when the population was declining. The low-level population showed a higher biomass than the high-level population (Fig. 7). It reached a peak of $3280 \mathrm{~g} \mathrm{~m}^{-2}$ in May, some two months before the peak in the high-level population, then declined in July and August. In September the plants disappeared completely. The lower-level population exhibited a higher protein (up to $31 \%$ ) and ash content than the high-level population throughout the study period and the low-level population of the second year exhibited higher protein values (up to $36 \%$ ) than that of the first year (Fig. 8).

Chondrus crispus is a very important perennial undergrowth species in the Fucus serratus vegetation as well as forming almost pure stands on open slopes and in tide pools. Biomass measurements were made on the stands on emerged slopes. Biomass reached a peak of $2480 \mathrm{~g} \mathrm{~m}^{-2}$ in August (Fig. 7) when the peak ash content of the plants $(48 \%)$ was reached (Fig. 8 ). These peaks coincided with the peak in water temperature. The minimum biomass $\left(129 \mathrm{~g} \mathrm{~m}^{-2}\right)$ was found in December. Protein varied from $30 \%$ in May to $14 \%$ in November.

Corallina officinalis forms perennial populations in shallow pools and lagoons, as well as in the fucacean undergrowth. Measurements were made on a population in a mid-eulittoral pool. Here the dominant $C$. officinalis was sometimes obscured by seasonal green epiphytes. Monostroma grevellei was a common spring epiphyte and Cladophora sp. was common in summer. Biomass of C. officinalis reached a peak in July of $3750 \mathrm{~g} \mathrm{~m}^{-2}$ and a minimum in January $\left(800 \mathrm{~g} \mathrm{~m}^{-2}\right)$ after the severe storms (Fig. 7). The protein content of the plants peaked at $7 \%$ in July and reached a minimum of $2 \%$ in February (Fig. 8). The ash content was high (up to $84 \%$ ) due to the $\mathrm{CaCO}_{3}$ encrustation of the thalli and showed little variation over the year.

Dumontia incrassata is a very prominent element of the spring flora on emerged slopes and tide pools in the mid-eulittoral. Measurements were made on an emerged slope. This species first appeared in March. The biomass increased sharply in April and reached a peak of $2560 \mathrm{~g} \mathrm{~m}^{-2}$ in May, then began to decline (Fig. 7). The plants disappeared from the vegetation completely by the end of July. In the second spring of observation the biomass was higher than in the first spring. Ash ranged from 30 to $44 \%$. Protein ranged from $25 \%$ in March of 1975 or $34 \%$ in March of 1976 to $21 \%$ during May to July 1975 (Fig. 8).

Petalonia fascia and $P$. zosterifolia are seasonal and present for only a short time but are very conspicuous during that time. $P$. zosterifolia appeared earlier, in March, forming 
pure stands on some exposed slopes in the upper part of the mid-eulittoral. Its biomass reached a peak of $586 \mathrm{~g} \mathrm{~m}^{-2}$ in April, then declined. The plants disappeared from the vegetation in June. Protein ranged from 25 to a peak of $29 \%$ in May. Ash ranged from 26 to $31 \%$. Petalonia fascia appeared later, at the beginning of April, and persisted longer into June before disappearing. It reached a peak biomass of $233 \mathrm{~g} \mathrm{~m}^{-2}$ in April. In contrast to $P$. zosterifolia it had a lower biomass, and a lower protein content (14 to $16 \%$ ). Ash ranged from 30 to $34 \%$.

Scytosiphon lomentaria is important in the spring vegetation in the eulittoral and persists for longer than Petalonia spp. On emerged slopes it was present mostly in mixed

Table 2. Biomass of mixed populations on emerged slopes

\begin{tabular}{|c|c|c|c|}
\hline Species & $\begin{array}{l}\text { Fresh weight } \\
\qquad\left(\mathrm{g} \mathrm{m}^{-2}\right)\end{array}$ & $\begin{array}{c}\text { Ash } \\
\text { (\% dry wt.) }\end{array}$ & $\begin{array}{c}\text { Protein } \\
\text { (\% dry wt.) }\end{array}$ \\
\hline \multicolumn{4}{|l|}{ March } \\
\hline Dumontia incrassata & 281 & 31 & 27 \\
\hline Cladophora rupestris & 80 & 38 & 13 \\
\hline Chondrus crispus & 270 & 25 & 28 \\
\hline$\Sigma$ & 631 & 29 & 26 \\
\hline \multicolumn{4}{|l|}{ April } \\
\hline Dumontia incrassata & 193 & 33 & 24 \\
\hline Chondrus crispus & 545 & 25 & 28 \\
\hline Cladophora rupestris & 90 & 25 & 13 \\
\hline Fucus serratus & 239 & 21 & 15 \\
\hline Fucus vesiculosus & 90 & 25 & 13 \\
\hline$\Sigma$ & 1157 & 25 & 24 \\
\hline \multicolumn{4}{|l|}{ May } \\
\hline Dumontia incrassata & 1170 & 42 & 23 \\
\hline Chondrus crispus & 697 & 29 & 30 \\
\hline Ceramium rubrum & 100 & 22 & 33 \\
\hline Petalonia zosterifolia & 230 & 26 & 26 \\
\hline$\Sigma$ & 2187 & 35 & 26 \\
\hline \multicolumn{4}{|l|}{ June } \\
\hline Dumontia incrassata & 500 & 34 & 20 \\
\hline Chondrus crispus & 379 & 25 & 24 \\
\hline Cladophora sericea & 150 & 55 & 27 \\
\hline Ulva lactuca & 350 & 35 & 22 \\
\hline$\Sigma$ & 1379 & 31 & 23 \\
\hline \multicolumn{4}{|l|}{ July } \\
\hline UIva lactuca & 1890 & 22 & 22 \\
\hline Enteromorpha linza & 1000 & 28 & 18 \\
\hline Chaetomorpha tortuosa & 560 & 31 & 22 \\
\hline Chondrus crispus & 500 & 33 & 22 \\
\hline$\Sigma$ & 3950 & 26 & 21 \\
\hline
\end{tabular}


Table 3. Biomass of mixed populations in tide pools

\begin{tabular}{|c|c|c|c|}
\hline Species & $\begin{array}{l}\text { Fresh weight } \\
\qquad\left(g \mathrm{~m}^{-2}\right)\end{array}$ & $\begin{array}{c}\text { Ash } \\
\text { (\% dry wt.) }\end{array}$ & $\begin{array}{c}\text { Protein } \\
\text { (\% dry wt.) }\end{array}$ \\
\hline \multicolumn{4}{|l|}{ March } \\
\hline Dumontia incrassata & 396 & 31 & 25 \\
\hline Rhodomela confervoides & 646 & 33 & 23 \\
\hline Ceramium rubrum & 48 & 25 & 50 \\
\hline Cystoclonium purpureum & 520 & 49 & 20 \\
\hline Polysiphonia nigrescens & 224 & 38 & 19 \\
\hline Polysiphonia urceolata & 87 & 33 & 33 \\
\hline$\Sigma$ & 1921 & 37 & 23 \\
\hline \multicolumn{4}{|l|}{ April } \\
\hline Dumontia incrassata & 1103 & 35 & 20 \\
\hline Scytosiphon lomentaria & 158 & 42 & 17 \\
\hline Chondrus crispus & 68 & 20 & 30 \\
\hline$\Sigma$ & 1329 & 34 & 21 \\
\hline \multicolumn{4}{|l|}{ May } \\
\hline Dumontia incrassata & 1492 & 42 & 21 \\
\hline Scytosiphon lomentaria & 239 & 38 & 15 \\
\hline Cladophora sericea & 366 & 36 & 50 \\
\hline Corallina officinalis & 126 & 73 & 6 \\
\hline Petalonia fascia & 24 & 50 & 50 \\
\hline$\Sigma$ & 2247 & 50 & 16 \\
\hline \multicolumn{4}{|l|}{ June } \\
\hline Scytosiphon lomentaria & 194 & 26 & 19 \\
\hline Cladophora sericea & 1193 & 26 & 22 \\
\hline$\Sigma$ & 1387 & 26 & 22 \\
\hline \multicolumn{4}{|l|}{ July } \\
\hline Chondrus crispus & 1185 & 33 & 19 \\
\hline Chaetomorpha tortuosa & 800 & 34 & 23 \\
\hline$\Sigma$ & 1985 & 34 & 19 \\
\hline \multicolumn{4}{|l|}{ July } \\
\hline Corallina officinalis & 3990 & 79 & 5 \\
\hline Ulva lactuca & 113 & 38 & 31 \\
\hline Chaetomorpha tortuosa & 1065 & 33 & 21 \\
\hline Ceramium rubrum & 2810 & 24 & 27 \\
\hline Chondrus crispus & 494 & 35 & 19 \\
\hline$\Sigma$ & 8472 & 67 & 10 \\
\hline \multicolumn{4}{|l|}{ December } \\
\hline Ceramium rubrum & 190 & 41 & 24 \\
\hline Rhodomela confervoides & 350 & 37 & 26 \\
\hline Polysiphonia nigrescens & 30 & 29 & 29 \\
\hline$\Sigma$ & 570 & 38 & 25 \\
\hline
\end{tabular}


stands but in tide pools occasional pure stands occurred. Its biomass peaked at $321 \mathrm{~g} \mathrm{~m}^{-2}$ in June. Ash ranged from $42 \%$ in April 1975 to $24 \%$ in July. Protein ranged from 15 to $19 \%$ in the first year and had a value of $30 \%$ in April 1976.

Additional measurements were made in spring and summer on mixed populations on emerged slopes (Table 2) and in spring, summer and winter on mixed tide-pool populations (Table 3). Data were obtained here for a total of 11 species on emerged slopes and 13 species in tide pools, although no more than 6 species were measured in any one month.

\section{DISCUSSION}

The nearest natural rock substrates to Helgoland are in Norway, France and Great Britain, and it is thus even more an island than the distance to the mainland coast of the German Bight would indicate. As has been noted previously by Nienburg (1925), den Hartog (1959) and the present authors (Markham \& Munda, 1980), certain vegetation features are unique to this island. The most obvious is the dominance of Fucus serratus, which occupies the greater part of the eulittoral and thus a wider range than on other European coasts. The peak biomass of $F$. serratus $\left(15 \mathrm{~kg} \mathrm{~m}^{-2}\right)$ recorded in summer is greater than that reported elsewhere, although the $8 \mathrm{~kg} \mathrm{~m}^{-2}$ reported for Sweden (Gislén, 1930) falls well within the seasonal range recorded here. Lüning (1969) recorded only $3700 \mathrm{~g} \mathrm{~m}^{-2}$ for $F$. serratus, but his measurements were made at the lower limit of the $F$. serratus vegetation and not in the area of maximum density. Baardseth (1958) recorded only 600 to $2400 \mathrm{~g} \mathrm{~m}^{-2}$ for Norway, much less than for Helgoland. Protein in F. serratus (and in F. spiralis) showed a minor peak in March and a higher peak in June, which is unlike the case in Norwegian fucoids, which show a single peak in March/April (Munda, 1967).

The dominance of Fucus serratus coincides with a very reduced role for $F$. spiralis and $F$. vesiculosus, which usually occur mixed with each other and with $F$. serratus and hardly form distinct belts at all. Belts of Ascophyllum nodosum (L.) Le Jol. and Pelvetia canaliculata (L.) Done et Thur., conspicuous on other European shores, are also lacking here, as is the characteristic belt normally found between fucoids and laminarians. At Helgoland, Fucus serratus extends down to where Laminaria digitata begins (Nienburg, 1925; den Hartog, 1959; Lüning, 1969; Markham \& Munda 1980). The lack of several characteristic belts is correlated with a general floristic impoverishment in terms of number of species compared to other European rocky shores.

The extrapolated values for biomass per square meter of the scattered Fucus spiralis and $F$. vesiculosus are higher at their peaks than those reported for Nova Scotia, Canada (Mann, 1972), Iceland (Munda, 1970 1972a, 1978, 1980), or Norway (Baardseth, 1958), but except for Norway $\left(600 \mathrm{~g} \mathrm{~m}^{-2}\right)$, all values fall within the seasonal range recorded here.

There are insufficient published data to compare the biomass figures for all species presented here, but several comparisons are possible. Enteromorpha linza, Ulva lactuca, Porphyra umbilicalis and Corallina officinalis have a similar biomass at Helgoland to that recorded for certain parts of Iceland (Munda, 1970, 1972a, 1977a, 1980). The lastnamed species, Corallina officinalis, has a higher biomass at Helgoland than the $1600 \mathrm{~g}$ $\mathrm{m}^{-2}$ recorded for the northern Adriatic (Munda, 1972b), but it is restricted mostly to 
tidepools at Helgoland and plays a significantly less important role in the eulittoral than in south and west Iceland where it forms conspicuous stands on emerged parts of the lower eulittoral and upper sublittoral (Munda, 1977a).

Porphyra linearis has a far lower biomass at Helgoland (maximum $137 \mathrm{~g} \mathrm{~m}^{-2}$ ) than in Iceland where values up to $1370 \mathrm{~g} \mathrm{~m}^{-2}$ have been recorded (Munda, 1972a).

Chondrus crispus is an important element of the undergrowth and some open areas of the Helgoland eulittoral. Its biomass is higher than in Iceland (Munda, 1972a, 1975, 1977b) but considerably less than on the Atlantic Coast of North America where it is harvested commercially. There, values up to $3500 \mathrm{~g} \mathrm{~m}^{-2}$ have been recorded in Nova Scotia (Mann, 1972) and up to $13000 \mathrm{~g} \mathrm{~m}^{-2}$ in New Hampshire (Mathieson \& Burns, 1975), while dry weight values are reported up to $400 \mathrm{~g} \mathrm{~m}^{-2}$ for Prince Edward Island (Taylor, 1970) and up to $1300 \mathrm{~g} \mathrm{~m}^{-2}$ for Massachusetts (Prince, 1971). On Helgoland, in agreement with findings in New Hampshire (Burns \& Mathieson, 1972), maximum growth and biomass appear to coincide with maximum water temperature.

The winter and early-spring flora of Helgoland is similar to the summer flora of south and west Norway (Printz, 1926; Sundene, 1953; Jorde, 1966), north Norway (Jaasund, 1965), the Faeroe Islands (Børgesen, 1905) and the Atlantic-water regions of Iceland (Jonsson, 1912; Munda, 1972a, 1975, 1977a, b). Among several examples are populations of Bangia atropurpurea, Acrosiphonia spp., Scytosiphon lomentaria, Petalonia spp. and Dumontia incrassata which occur in winter/spring or early spring at Helgoland, but in summer in Scandinavia.

The effects of the severe storm of January 1976 were evident in a great many examples of sharp changes in vegetation and biomass, both in comparing the months before and after the storm and in comparing the two springs of observation. One such change was evident in protein content. In several seasonal species which reappeared as new generations after the severe storms, the protein content of the new generations was notably higher. Examples are Porphyra linearis, Rhodomela confervoides, Dumontia incrassata, and Scytosiphon lomentaria (Fig. 8). This points out the dangers inherent in extrapolating too widely from single surveys done in single years, a point made earlier for Helgoland by Nienburg (1925). The present study covered only one year, but as this year included an unusually warm summer and an unusually stormy winter, the vegetation patterns and the biomass values reported here should represent a reasonably good approximation of the range to be expected on this isolated island.

Acknowledgements. This work was carried out at the Biologische Anstalt Helgoland, Germany, while both of us were in receipt of research fellowships from the Alexander von Humboldt Foundation, Bonn-Bad Godesberg.

\section{LITERATURE CITED}

Anonymous, 1976. Tide tables 1977. Europe and West Coast of Africa, including the Mediterranean Sea. U.S. Dept. Comm., Nat. Ocean. Atmos. Admin., Rockville.

Baardseth, E., 1958. The quantitative composition of the fucoid zones. - Norsk Inst. Tang-og Tareforsk. Rep. 20, 7-10.

Børgesen, F., 1905. The algae vegetation of the Faeröse coasts, with remarks on their phytogeography, - Bot. Faeröes 3, 681-834.

Burns, R. \& Mathieson, A. C., 1972. Ecological studies of economic red algae. 2. - J. exp. mar. Biol. Ecol. 8, 1-6. 
Den Hartog, C., 1959. The epilithic algal communities occurring along the coast of the Netherlands. - Wentia 1, 1-241.

Gislén, T., 1930. Epibioses of the Gullmar fjord II. Kristineberg Zoologiska Station 1877-1927. K. svenska Vetensk Akad. Skr. - Ser. 4, 1-380.

Jaasund, E., 1965. Aspects of the marine algal vegetation of North Norway. - Bot. Gothoburg. 4, $1-174$.

Jonsson, $H$., 1912. The marine algal vegetation. - Botany Icel. 1, 1-186.

Jorde, I., 1966. Algal associations of the coastal area south of Bergen, Norway, - Sarsia 23, 1-52.

Kornmann, P., 1961. Zur Kenntnis der Porphyra-Arten von Helgoland. - Helgoländer wiss. Meeresunters. $8,176-192$.

Kornmann, P. \& Sahling, P. H., 1977. Meeresalgen von Helgoland. - Helgoländer wiss. Meeresunters. 29, 1-289.

Kuckuck, P., 1892. Über marine Vegetationsbilder. - Ber. dt. bot. Ges. 15, 441-447.

Lewis, J. R., 1964. The ecology of rocky shores. The English Univ. Press, London, $323 \mathrm{pp}$.

Lüning, K., 1969. Standing crop and leaf area index of the sublittoral Laminaria species near Helgoland. - Mar. Biol. 3, 282-286.

Lüning, K., 1970. Tauchuntersuchungen zur Vertikalverbreitung der sublittoralen Helgoländer Algenvegetation. - Helgoländer wiss. Meeresunters. 21, 271-291.

Mann, K., 1972. Ecological studies of the seaweed zone in a marine bay on the Atlantic Coast of Canada. I. Zonation and biomass of seaweeds. - Mar. Biol. 12, 1-10.

Markham, J. W. \& Munda, I. M., 1980. Algal recolonization in the rocky eulittoral of Helgoland, Germany. - Aquat. Bot. 9, 33-71.

Mathieson, A. C. \& Burns, R. L., 1975. Ecological studies of economic red algae. V. Growth and reproduction of natural and harvested populations of Chondrus crispus Stackhouse in New Hampshire. - J. exp. mar. Biol. Ecol. 17, 137-156.

Munda, I., 1967. Der Einfluß des Salzgehaltes auf die chemische Zusammensetzung, Wachstum und Fruktifizierung von eigenen Fucaceen. - Nova Hedwigia 13, 471-508.

Munda, I., 1970. A note on the densities of benthic algae along a littoral rocky slope in Faxaflói, Southwest Iceland. - Nova Hedwigia 19, 535-550.

Munda, I., 1972a. On the chemical composition, distribution and ecology of some common benthic marine algae from Iceland. - Botanica mar. 15, 1-45.

Munda, I., 1972b. The production of biomass in the settlement of benthic algae of the Northern Adriatic. - Botanica mar. 15, 218-244.

Munda, I., 1975. Hydrographically conditioned floristic and vegetation limits in Icelandic coastal waters. - Botanica mar. 18, 224-235.

Munda, I., 1977a. A comparison of the north and south European association of Corallina officinalis. - Hydrobiologia 52, 73-87.

Munda, I., 1977b. The structure and distribution of Gigartina stellata (Stackh.) Batt. and Chondrus crispus Stackh. associations in Icelandic waters. - Botanica mar. 20, 291-301.

Munda, I., 1978. Survey of the benthic algal vegetation of the Dýrafjördur, Northwest Iceland. Nova Hedwigia 29, 281-403.

Munda, I., 1980. Survey of the benthic algal vegetation of the Borgafjördur, Southwest Iceland. Nova Hedwigia 32, 855-927.

Nienburg, W., 1925. Die Besiedlung des Felsstrandes und der Klippen von Helgoland. 2. Die Algen. - Wiss. Meeresunters. (Abt. Helgoland) 15, 1-15.

Nienburg, W., 1927. Zur Ókologie der Flora des Wattenmeeres. I. Teil. Der Königshafen bei List auf Sylt. - Wiss. Meeresunters. (Abt. Kiel) 20, 147-196.

Nienhuis, P., 1970. The benthic algal communities of flats and salt marshes in the Grevelingen, a sea-arm in the south-western Netherlands. - Neth. J. Sea Res. 5, 20-49.

Prince, J. S., 1971. An ecological study of the marine red alga Chondrus crispus in the waters off Plymouth, Massachusetts. Ph. D. Thesis, Cornell University, Ithaca, N.Y., 193 pp.

Printz, H., 1926. Die Algenvegetation des Trondheimfjordes. - Skr. norske VidenskAkad. 5, 1-274. Sundene, O., 1953. The algal vegetation of the Oslofjord. - Skr. norske VidenskAkad. 2, 1-244.

Taylor, A. R. A., 1970. Studies of the biology and ecology of Chondrus crispus (Irish moss) on Prince Edward Island. - Serv. Proj. Rep. Ottawa Dept. Fish. Forest. Ind. Develop. Branch, Fish. 25, 1-30. 